\title{
PEMIKIRAN AL-GHAZALI DAN IBNU KHALDUN TENTANG EKONOMI (UANG DAN HARGA)
}

Dewi (90100118101)

Ekonomi Islam C 2018

Ekonomi adalah persoalan yang tidak mungkin lagi bisa kita pungkiri dalam kehidupan ini karena hampir setiap aktivitas keseharian manusia pasti bersinggungan dengan persoalan ekonomi. Sehingga untuk mengingat maupun mempelajari persoalan ekonomi, kita tentunya membutuhkan pengetahuan mengenai pemikir-pemikir ekonomi untuk dijadikan sebagai rujukan ataupun pertimbangan dalam menyelesaikan setiap persoalan ekonomi yang dihadapi. Jika kembali mengingat sejarah pemikiran ekonomi, pada muasalnya kita akan flashback pada awal hadirnya Islam di dunia. Namun kali ini kita tidak akan membahas sejarah awal dari pemikiran ekonomi karena pasti rentetannya akan sangat panjang jika dijelaskan tetapi fokus artikel ini adalah membahas tokoh-tokoh pemikir ekonomi jauh setelah Islam datang. Dalam lintasan sejarah umat Islam di dapati banyak sekali tokoh yang membincangkan persoalan ekonomi seperti Ibnu Khaldun dan Al-Ghazali. Kedua tokoh ini merupakan pemikir ekonomi Islam yang cukup terkenal hingga sekarang dan secara sosiologis keduanya turut membangun teori-teori atau konsep ekonomi.

Ibnu Khaldun atau yang bernama lengkap Abd al-Rahman bin Muhammad bin Khaldun al-Hadrawi (732-808 H/1332-1406 M) adalah seorang sejarahwan muslim dari Tunisia. Ibnu Khandun dikenal sebagai bapak pendiri ilmu istoriografi, sosiologi, dan ekonomi. Ia juga dikenal sebagai bapak ekonomi karena pemikirannya tentang teori ekonomi yang bisa dibilang logis dan realistis yang jauh telah dikemukakannya sebelum Adam Smith dan David Ricardo mengemukakan teori-teori ekonominya. Ibnu Khaldun sudah hidup di zaman mata uang sudah menjadi alat penghargaan. Dimana ketika itu dinar dan dirham merupakan mata uang dari emas dan perak. Ketika itu, ia sudah mengetahui bahwa sistem ekonomi yaitu dengan sistem tukar menukar barang akan mulai ditinggalkan dan akan beralih ke sistem ekonomi modern yaitu jual beli dengan perantara uang. Pada saat itu terjadi, maka emas dan perak akan berada pada tingkat standar (ukuran nilai). Dalam konsep ekonomi, Ibnu Khaldun menuangkan pemikiran ekonominya dalam salah satu karyanya yang berjudul "Muqaddimah". Dalam bukunya AlMuqaddimah, menurutnya konsep uang adalah bahwa uang merupakan apa yang digunakan manusia sebagai standar ukuran nilai harga, media transaksi pertukaran dan media simpanan. Ibnu Khaldun menjelaskan emas dan perak adalah acuan nilai dari uang artinya bahwa uang 
tidak harus terbuat dari emas dan perak, tetapi penerbitan uang harus sesuai dengan nilai harta (cadangan) yang dimiliki oleh pemerintah. Uang tidak perlu mengandung emas dan perak tetapi emas dan perak hanya sebagai standar nilai uang sehingga dengan pernyataan tersebut, pemerintah wajib menjaga nilai uang yang dicetak. Ibnu Khaldun memprediksikan bahwa dalam perkembangan perekonomian standar uang akan mengalami perubahan. Artinya bahwa dari masa ke masa sejalan dengan perkembangan ekonomi, standar uang yang tadinya tinggi kemudian berubah menjadi rendah. Misalnya, uang 1000 yang dulunya bisa membeli 5 permen kemudian berubah dengan hanya bisa mendapatkan 3 permen dan hal ini terbukti terjadi di zaman sekarang. Ia juga berpendapat bahwa Negara yang kaya tidaklah diukur dari banyaknya uang yang dimilikinya tetapi ditentukan berdasarkan tingkat produksi dan neraca pembayaran positif. Jika negara mencetak uang sebanyak-banyknya tetapi tidak mendorong perkembangan pertumbuhan sektor produksi maka uang berlimpah tersebut tidak ada nilainya, yang menjadi penunjang pembangunan suatu negara adalah sektor produksi karena dengan sektor produksi, ia akan menyerap tenaga kerja, meningkatkan pendapatan pekerjaan, dan menimbulkan permintaan (pasar) terhadap produksi lainnya. Ibnu Khaldun juga mengatakan bahwa uang merupakan yang menentukan taraf kemakmuran. Oleh sebab itu, kemakmuran yang dinikmati adalah suatu hasil yang dilaksanakan oleh uang dalam negeri-negeri kaya yang dapat mempengaruhi percepatan peredaran uang dan memperbanyak transaksi perniagaan dan seterusnya menambah lagi jumlah uang yang beredar.

Menurut Ibnu Khaldun, Harga merupakan hasil dari hukum permintaan dan penawaran. Semua barang akan terkena fluktuasi harga yang tergantung pada pasar, kecuali pada harga emas dan perak karena ia merupakan standar moneter. Ibnu Khaldun berpendapat bahwa permintaan dan penawaran mempengaruhi dalam menentukan harga. Ia menekankan bahwa suatu peningkatan dalam permintaan atau penurunan dalam penawaran akan menimbulkan kenaikan dalam harga, sebaliknya suatu penurunan dalam permintaan atau peningkatan dalam penawaran akan menimbulkan penurunan dalam harga (Ain Rahmi, 2018). Ia juga percaya bahwa tinggi rendahnya suatu harga dapat berdampak buruk bagi masing-masing produsen maupun konsumen. Seperti ketika harga yang terlalu rendah akan merugikan bagi para pedagang dan juga akan mendorongnya untuk keluar dari pasar. Begitupun sebaliknya harga yang terlalu tinggi akan merugikan para konsumen. Yang pada akhirnya hal ini akan mengakibatkan terjadinya penumpukan kekayaan. Adapun faktor yang menentukan naik turunnya permintaan menurutnya adalah permintaan, tingkat keuntungan relative, usaha manusia, tenaga buruh yang masuk, kemampuan tekhnik dan perkembangann masyarakat. 
Sedangkan dalam permintaan faktor yang menentukannya adalah pendapatan, jumlah penduduk, adat-istiadat, pembangunan dan kemakmuran masyarakat.

Berbeda dengan Ibnu Khaldun yang terlahir dari keluarga bangsawan, Abu Hamid Muhammad bin Muhammad bin at-Tusi al-Ghazali atau yang lebih dikenal dengan al-Ghazali, terlahir dari keluarga yang fakir namun terkenal keshalehannya. Ia lahir di Desa dekat Thus bagian dari kota Khurasan, Iran pada tahun 450 H/1056 M. Semasa hidupnya ia seringkali berpindah-pindah kota guna untuk menuntut ilmu. Al-Ghazali memperdalam ilmunya dengan belajar ke sejumlah ulama, ia juga pernah menduduki posisi sebagai guru besar di salah satu madrasah di Baghdad yaitu madrasah Nizhamiyah karena kecerdasannya.

Jika dilihat dari sejarah pemikiran Islam, al-Ghazali hidup pada masa yang ditandai dengan maraknya korupsi oleh pihak-pihak yang tidak bertanggung jawab. Pada masanya kondisi ekonomi umat Islam bisa dikatakan membaik dan bahkan bisa dikatakan mencapai taraf kemakmuran. Namun, "kemakmuran" ini sepertinya hanya sebagai kata hiasan saja karna pada saat itu masih meluasnya kesenjangan antara si kaya dan si miskin. Sedangkan kemakmuran terjadi jika kesenjangan antara kaya dan miskin semakin jauh. Negara yang makmur adalah negara yang telah mencapai standar kehidupan seluruh masyarakatnya. Menurut al-Ghazali, untuk meningkatkan kemakmuran ekonomi dibutuhkan peran pemerintah yang baik. Untuk meningkatkan kemakmuran ekonomi, negara harus menegakkan keadilan, kedamaian, keamanan dan stabilitas. Oleh karena itu negara bertanggung jawab dalam menciptakan kondisi yang nyaman untuk meningkatkan kemakmuran dan pembangunan ekonomi. Al-Ghazali menjelaskan tentang lembaga Hisbah yang bertugas sebagai badan pengawas. Pandangan serupa dikemukakan oleh Ibnu Taymiyah. Ia sangat mendukung lembaga ini dalam menyelesaikan persoalan pasar, termasuk iklan palsu, pencurian timbangan, transaksi yang menyalahi syariat, dan lain-lain (Lilik Rahmawati, 2012).

Penerapan barter menjadi problem yang sulit untuk diterapkan dalam sistem ekonomi, menurutnya untuk mengatasi permasalahan barter dibutuhkannnya uang sebagai alat tukar yang lebih memudahkan. Al-Ghazali memandang bahwa uang dapat memiliki nilai jika digunakan dalam suatu pertukaran. Ia juga menegaskan bahwa uang tidak diinginkan karena uang itu sendiri. Lebih jauh, Al-Ghazali menyatakan bahwa tujuan satu-satunya dari emas dan perak adalah untuk dipergunakan sebagai uang (dinar dan dirham). Al-Ghazali melarang menimbun uang, menurutnya tujuan uang agar beredar di masyarakat adalah sebagai sarana transaksi dan bukan untuk dimonopoli dan juga dengan penimbunan uang akan berdampak 
pada instabilitas perekonomian suatu masyarakat. Ia juga setuju dengan penghapusan riba dalam masyarakat, alasannya mengharamkan riba adalah didasarkan pada motif dicetaknya uang yaitu sebagai alat tukar dan standar nilai barang. Riba merupakan tindakan yang keluar dari tujuan awal penciptaan uang dan dilarang keras oleh agama.

Zakat merupakan sumber pendapatan utama bagi negara Muslim sebelumnya. Hal ini berbeda pada masa al-Ghazali, menurutnya sumber pendapatan negara pada saat itu umumnya didapatkan dari hasil yang haram. Bukan hanya zakat, sedekah, fa'i maupun ghanimah tidak ada pada masanya. Adapun sumber pemasukan negara yang ada seperti jizyah, tetapi sesuatu dikatakan halal apabila zat dan cara memperolehnya dengan cara yang halal pula. Namun jizyah yang diberlakukan pada saat itu dikumpulkan dengan cara yang ilegal menurutnya. AlGazali menyebutkan bahwa salah satu sumber pendapatan yang halal adalah harta tanpa ahli waris yang pemiliknya tidak dapat dilacak, ditambah sumbangan sedekah atau wakaf yang tidak ada pengelolanya (Sirajuddin, 2016). Ia juga berpendapat bahwa negara dalam memanfaatkan keuangan negara haruslah bersifat fleksibel yang berlandaskan kesejahteraan. Berkaitan dengan pajak, menurut al-Ghazali negara tidak boleh terlalu membebankan kewajiban pajak bagi masyarakat, Apa yang ia ambil dalam bentuk pajak harus sedang, dan apa yang ia berikan harus sedang pula, karena masing-masing memiliki batas dan ukuranukurannya. Hal ini bertujuan agar masyarakat menjadi makmur dan berkembang. Dalam distribusi keuangan negara, al-Ghazali menyarankan agar bukan hanya penguasa-penguasa penting yang menikmatinya tetapi didistribusikan kepada kepentingan umum agar manfaatnya dapat dirasakan oleh semua masyarakat. 


\section{DAFTAR PUSTAKA}

Rahmawati, L. (2012). Konsep Ekonomi Al-Ghazali. Maliyah, 2 (1), 329-345.

Rahmi, A. (2018). Pandangan Ibnu Khaldun Terhadap Nilai Uang dalam Sektor Moneter. Al-Maslahah, 14 (2), 257-276.

Sirajuddin. (2016). Konsep Pemikitan Al-Ghazali. Laa Maisyir, 3(1), 46-60. 